\title{
Modifikasi dan Pengujian Sistem Penyemprot Padi dengan Penambahan Pompa Elektrik
}

\author{
Modification and Performance Test on Rice Sprayer System \\ by Adding Electric Pump
}

\begin{abstract}
Marno $^{1 *}$, Slamet Abadi ${ }^{2}$, Eri Widianto ${ }^{3}$, Uut Ulis Utomo ${ }^{4}$, Najmudin Fauji ${ }^{5}$, Rizal Hanifi ${ }^{6}$ 1,3,4,5,6 Program Studi Teknik Mesin, Fakultas Teknik Universitas Singaperbangsa Karawang, 2Program Studi Agroteknologi, Fakultas Pertanian Universitas Singaperbangsa Karawang, Jalan H.S. Ronggowaluyo, Telukjambe Timur, Karawang, Indonesia 41361

*email: indexindocv@gmail.com
\end{abstract}

DOI;

10.30595/jrst.v4i1.3658

Histori Artikel:

Diajukan:

$06 / 12 / 2018$

Direvisi:

$23 / 10 / 2019$

Diterima:

$06 / 03 / 2020$

\begin{abstract}
ABSTRAK
Telah dilakukan penelitian tentang modifikasi dan pengujian sistem penyemprot padi dengan penambahan pompa elektrik $12 \mathrm{v}$. Tekanan penyemprotan standar ditargetkan sebesar 1,0 - 1,6 bar $\left(6,8 \mathrm{~kg} / \mathrm{cm}^{2}\right)$. Pengaturan tekanan dan volume penyemprotan akan dilakukan oleh potensiometer. Penyemprot hasil modifikasi mampu tetap bekerja ketika daya baterai habis, karena konstruksi dasar pompa manual tetap dipertahankan. Setelah percobaan didapatkan data bahwa tekanan maksimal pompa manual pada waktu penyemprotan adalah 1,2 bar, sementara untuk pompa DC tekanannya mencapai 1,9 bar (potensiometer 1 putaran penuh 3,68 k 2 ). Sementara untuk volume penyemprotan bonggol padi pada kondisi nozzle standar didapatkan untuk pompa manual adalah $1376 \mathrm{~L} /$ ha dan $2304 \mathrm{~L} / \mathrm{ha}$ untuk pompa DC (potensiometer 1 putaran). Untuk hasil pengukuran volume penyemprotan dengan nozzle 1 lubang (3 lubang ditutup dari 4 lubang) pompa manual $272 \mathrm{~L} /$ ha dan pompa DC $336 \mathrm{~L} /$ ha (potensiometer 1 putaran).
\end{abstract}

Kata Kunci: penyemprot, pompa elektrik, padi

\begin{abstract}
Modification and performance test on rice sprayer system by adding electric pump $12 \mathrm{v}$ have been done. The standard of spraying pressure is $1.0-1.6 \mathrm{bar}\left(6.8 \mathrm{~kg} / \mathrm{cm}^{2}\right)$. The pressure arranges by the potentiometer. The sprayer can work if the battery is empty because the construction of manual pump still there. After research, we get the maximum pressure of manual pump in spraying time is 1.2 bar, while the pressure of the DC pump until 1.9 bar (potentiometer in 1 revolution $3.68 \mathrm{k} \Omega$ ). While for spraying the rice plant hump in standard nozzle condition is got $1376 \mathrm{~L} /$ ha for manual pump and $2304 \mathrm{~L} /$ ha for DC pump (potentiometer in 1 revolution). For the result of spraying with one hole nozzle ( 3 holes is closed from 4 holes) is got $272 \mathrm{~L} / \mathrm{ha}$ for manual pump and $336 \mathrm{~L} /$ ha for DC pump (potentiometer in 1 revolution).
\end{abstract}

Keywords: sprayer, electric pump, rice 


\section{PENDAHULUAN}

Meningkatnya kebutuhan hidup dan perkembangan teknologi, peralatan yang diciptakan manusia juga semakin canggih dan praktis. Selain memudahkan dalam beraktifitas, juga dapat menunjang hasil produksi. Luas lahan pertanian di Indonesia berkisar 13 juta ha. Berdasarkan data Badan Litbang Pertanian Tahun 2013, rata-rata serangan gulma pada lahan pertanian sekitar 30-40 \% setiap hektar, maka dapat diasumsikan tutupan gulma secara keseluruhan dapat mencapai 5.2 juta ha, sehingga diperlukan pengendalian gulma. Pengendalian gulma dapat dilakukan dengan cara manual maupun kimiawi (Litbang Pertanian, 2013).

Pengendalian gulma secara manual dilakukan dengan mencabut gulma secara langsung menggunakan tangan atau alat lainnya. Pengendalian secara manual saat ini kurang dikehendaki karena biaya tenaga kerja yang mahal (Guntoro, Agustina, \& Yursida, 2014). Alternatif pengendalian gulma yang lebih disarankan adalah secara kimiawi menggunakan herbisida. Pengendalian dengan herbisida hendaknya menggunakan senyawa kimia yang selektif untuk menghambat dan mematikan pertumbuhan gulma (Prasetio \& Wicaksono, 2017).

Proses pemberian zat aditif (pupuk maupun pestisida) memiliki peranan penting dalam perkembangan industri pertanian. Proses ini bertujuan untuk mengoptimalkan pertumbuhan tanaman budidaya serta menjaga tanaman dari hama yang menghambat pertumbuhan dan produktivitas tanaman. Pemberian pupuk dan pestisida berbentuk padat dapat dilakukan melalui akar tanaman. Cara lain yaitu melalui penyemprotan daun menggunakan pupuk atau pestisida cair. Cairan atau larutan yang akan diaplikasikan dipecah menjadi butiran-butiran halus sehingga dapat disebarkan secara merata pada permukaan atau ruang yang dilindungi (Harefa, 1997). Butiran berukuran kecil atau halus penyerapannya ke dalam jaringan tanaman lebih baik (Kurniawan, 2014).

Pemberian zat aditif cair pada pertanian menengah ke bawah di Indonesia biasanya menggunakan alat bantu berupa sprayer gendong. Alat yang selama ini sudah beredar di pasaran secara umum memiliki bentuk fisik berupa tabung berisi pupuk yang digendong dengan selang yang menghubungkan tabung ke tongkat sprayer dimana pupuk akan disemprotkan keluar. Ada dua jenis sistem yang digunakan untuk memompa cairan pupuk atau pestisida keluar dari tabung. Pertama adalah sistem tabung bertekanan, dimana tabung harus dipompa secara manual sampai mencapai tekanan tertentu sebelum digunakan, kemudian dengan tekanan tersebut cairan dalam tabung dapat keluar dan dikontrol dengan membuka-tutup katup yang ada di tongkat sprayer. Jenis yang kedua adalah tabung dengan tuas pemompa yang harus diayun secara simultan saaat ingin memompa cairan pupuk atau pestisida keluar dari nozzle pada tongkat sprayer. Jenis semprotan cairan yang keluar dari nozzle dapat diatur sesuai penggunaan.

BPTP Yogyakarta menyatakan sprayer yang paling banyak diminati dan digunakan oleh petani kalangan menengah ke bawah adalah sprayer tipe gendong (Balai Pengkajian Teknologi Pertanian Yogyakarta, 2007). Direktorat Jenderal Prasarana dan Sarana Pertanian Kementrian Pertanian menyatakan tentang keunggulan hand sprayer. Keunggulan hand sprayer diantaranya mudah dalam penggunaannya karena dimensi relatif kecil, teknologi yang digunakan sederhana sehingga mudah perawatannya selain itu juga relatif murah (LAKIP, 2012). Pengembangan sprayer selama ini lebih kearah pemanfaatan energi motor bensin, penggunaan aki, ataupun penggunaan traktor sebagai penghasil energi untuk memompa sprayer. Sprayer gendong bermotor merupakan sprayer yang bertenaga motor bakar internal atau motor listrik. Menurut (Hermawan, 2012) penggunaan knapsack power sprayer memiliki mutu penyemprotan yang lebih baik dibandingkan sprayer gendong manual dengan membandingkan kapasitas rata-ratanya, sprayer manual memiliki kapasitas 0.37 ha/jam per orang, sedangkan knapsack power sprayer memiliki kapasitas mencapai $0.4 \mathrm{ha} /$ jam per orang. Pengaruh kestabilan tekanan pada penerapan sprayer bermotor memiliki pengaruh yang baik pada efektivitas penyemprotan, hal ini dipengaruhi oleh sumber tenaga yang berasal dari motor bakar internal sehingga debit keluaran dan tekanan kerja lebih stabil, jika dibandingkan dengan sprayer manual yang menggunakan tenaga manusia sehingga tekanan yang dihasilkan tidak stabil (Aspar, 2012). Menurut (Harry L. Field and John B. Solie, 2007), kapasitas keluaran adalah fungsi dari debit aliran pada nosel dan kecepatan sprayer. Akan tetapi faktor harga dan tingginya biaya operasional sprayer yang menggunakan energi motor bensin ataupun traktor menjadikan para petani kecil tidak mampu untuk menggunakan. 
Berdasarkan uraian di atas, maka dalam penelitian ini dilakukan modifikasi hand sprayer. Modifikasi hand sprayer dilakukan dengan mengubah sistem bertenaga mekanik (pompa manual) menjadi bertenaga hybrid (mekanik dan pompa) dengan otomasi preassure switch. Pompa mini akan menyuplai udara bertekanan ke dalam tangki air. Tekanan ini akan diatur preassure switch agar tetap stabil antara 1,0 - 1,6 bar. Aki kering bertegangan 12 $\mathrm{V}$ dan daya 1,2 Ah akan digunakan untuk menyuplai listrik ke pompa tersebut. Tangki penyemprot ini tetap bisa dioperasikan apabila daya baterai telah habis. Konstruksi pompa manual dari tangki tetap dipertahankan, sehingga alat penyemprot dapat dioperasikan secara manual ketika daya baterai habis. Dengan dukungan tenaga hybrid ini diharapkan alat ini dapat berfungsi maksimal untuk mendukung kinerja petani.

\section{METODE PENELITIAN}

Secara umum, tahapan penelitian yang akan dilakukan sesuai dengan skema diagram alir pada Gambar 1.

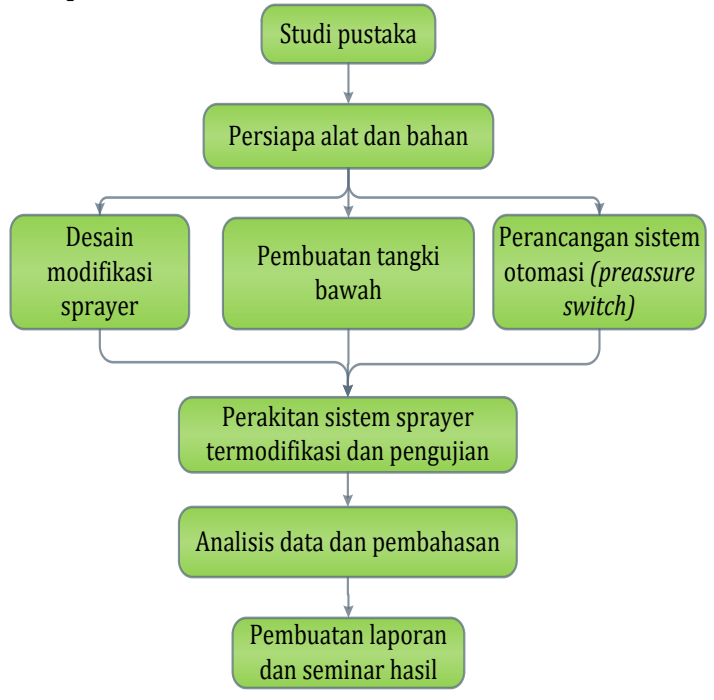

Gambar 1. Diagram alir penelitian

Bahan dan peralatan yang digunakan dalam penelitian ini antara lain sprayer kapasitas 14L, baterai aki 12 volt, pompa listrik (tekanan 100 psi, tegangan 12 volt, dan arus 3 A), potensiometer, kabel, saklar, kran, selang, pressure gauge, holder dan belt. Spesifikasi sprayer yang dimodifikasi ditunjukkan pada Tabel 1.
Tabel 1. Spesifikasi sprayer yang digunakan

\begin{tabular}{ll}
\hline Spesifikasi & Keterangan \\
\hline Merc & Swan \\
Type & SA -14 \\
Tank Material & HQ stainless steel \\
Tank Capacity & $13.5 \mathrm{~L}$ \\
Working pressure & $2.0-6.0 \mathrm{~kg} / \mathrm{cm}^{2}$ \\
Net weigh & $4.6 \mathrm{~kg}$ \\
Dimension & $33.5 \times 17.5 \times 50 \mathrm{~cm}$ \\
\hline
\end{tabular}

Sprayer gendong manual merk Swan merupakan salah satu sprayer yang banyak digunakan petani dan mudah diperoleh di pasaran. Desain modifikasi sprayer ditunjukkan pada Gambar 2 dan Gambar 3.

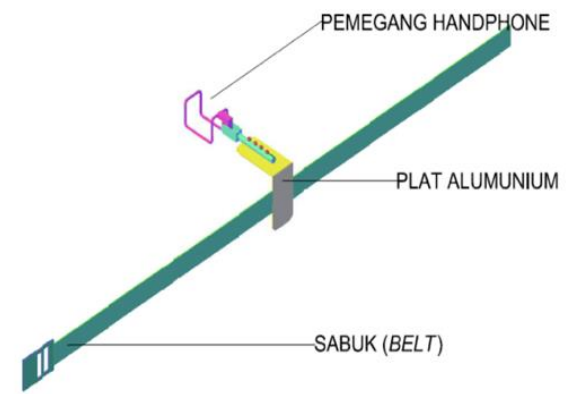

Gambar 2. Holder

Holder digunakan untuk memegang handphone. Holder didesain seperti sistem sabuk, yang akan dipasang pada badan bagian perut operator.

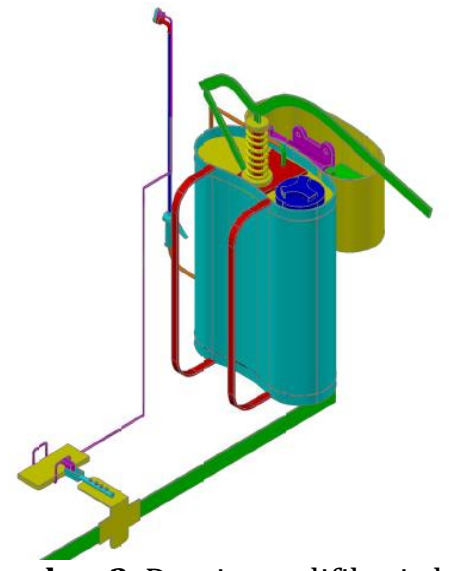

Gambar 3. Desain modifikasi alat

Modifikasi hand sprayer dilakukan dengan mengubah sistem menjadi bertenaga hybrid (mekanik dan pompa) dengan otomasi preassure switch. Pompa mini akan menyuplai udara bertekanan ke dalam tangki air. Aki kering bertegangan $12 \mathrm{~V}$ dan daya 1,2 Ah akan digunakan untuk menyuplai listrik ke pompa tersebut. Tangki penyemprot ini tetap bisa dioperasikan apabila daya baterai telah habis.

Langkah kerja modifikasi hand sprayer 
a. Melakukan pengujian peforma pompa manual meliputi tekanan kerja (P), debit (Q), pengujian dilakukan pada nozzle standar dan nozzle 1 lubang. Tahapanya:

- Siapkan kelengkapan alat (pressure gauge, gelas, dan suntikan)

- Pasang pressure gauge dan hubungkan pressure gauge ke handle.

- Lakukan pemompaan dengan menggerakkan tuas ke atas dan ke bawah sampai pompa manual terasa berat (tekanan maksimal)

- Arahkan nozzle ke gelas dan buka nozzle

- Lakukan selama 5 detik (gunakan stopwatch)

- $\quad$ Catat tekanan pada pressure gauge dan hitung volume air di gelas dengan suntikan

b. Melakukan pengujian performa pompa DC meliputi tekanan kerja (P), debit (Q), untuk setiap putaran potensiometer $(1 / 3,2 / 3$, dan 1 putaran) tentukan juga nilai hambatan potensiometer, pengujian dilakukan pada nozzle standar dan nozzle 1 lubang. Langkahnya:

- Siapkan kelengkapan alat (pessure gauge, gelas, dan suntikan)

- Pasang pressure gauge dan hubungkan pressure gauge ke handle

- Arahkan nozzle ke dalam gelas

- Hidupkan pompa DC pada posisi putaran potensiometer $1 / 3,2 / 3,1$ (dilakukan pada gelas yang berbeda untuk setiap posisi potensiometer)

- Lakukan selama 5 detik (gunakan stopwatch)

- Catat tekanan pada pressure gauge dan hitung volume air di gelas dengan suntikan

c. Perhitungan volume penyemprotan per ha. Tahapan:

- Hitung jumlah padi per m2 dengan mengambil 3 sampel di tempat berbeda (ambil jumlah padi yang terbanyak)

- Hitung jumlah padi per ha dari data tersebut

- Hitung volume penyemprotan per ha jika lama penyemprotan per bonggol $0,5 \mathrm{~s}$

d. Perbandingan berat alat sebelum dan sesudah modifikasi. Langkahnya:

- Siapkan timbangan dan timbang berat sprayer standar dan sprayer modifikasi dan berat sprayer modifikasi yang terisi penuh cairan
- Bandingkan berat tersebut dengan beban aman (beban gendong) yang bagi manusia

e. Menguji performa baterai dengan menghitung daya tahan baterai.

\section{HASIL DAN PEMBAHASAN}

Modifikasi pompa penyemprot pertanian telah dilakukan dengan penambahan pompa listrik 12 v DC pada pompa sprayer manual dan pemasangan kamera endoskopi pada nozzle-nya untuk ketepatan penyemprotan. Penyemprot yang telah dimodifikasi dapat dilihat pada Gambar 4.
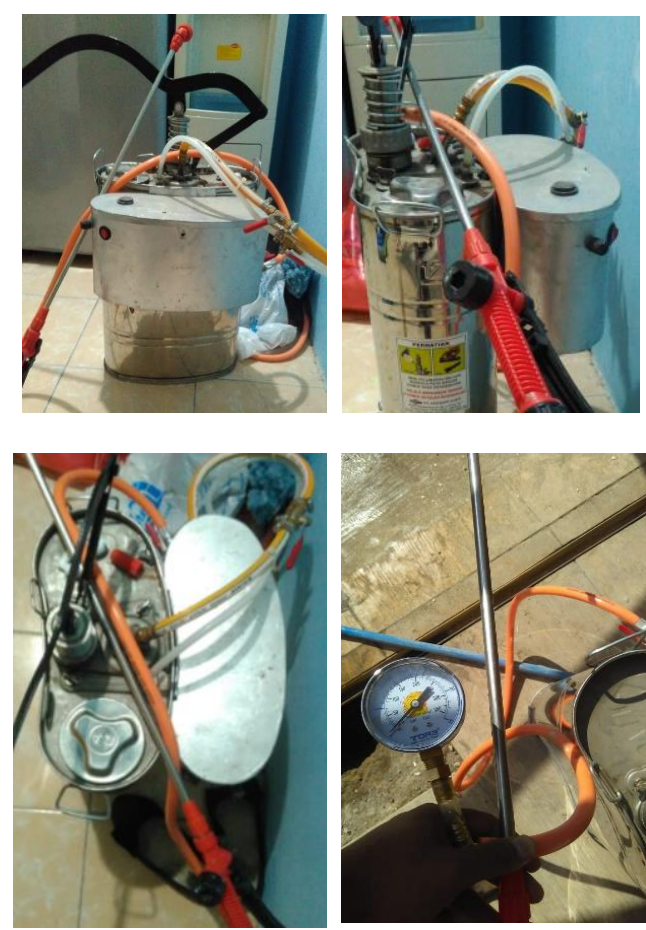

Gambar 4. Hasil modifikasi sprayer

Alat semprot padi merk swan yang semula hanya dapat dioperasikan dengan pompa manual setelah dimodifikasi dapat dioperasikan dengan pompa manual maupun pompa dc 12 V. Konstruksi pompa manual dari tangki tetap dipertahankan, sehingga alat penyemprot dapat dioperasikan secara manual ketika daya baterai habis.

\section{a. Performa Pompa Manual dan Pompa DC}

Pada penelitian ini akan dibandingkan nilai $\mathrm{Q}$ antara nozzle standar dan nozzle 1 lubang (3 lubang ditutup). Nozzle 1 lubang ini dipakai karena dalam penyemprotan bonggol padi cairan langsung tepat mengarah pada bonggol padi sehingga memerlukan cairan yang lebih sedikit. Hasil pengukuran performa pompa manual dapat dilihat pada Tabel 2 . 
Tabel 2. Performa pompa manual

\begin{tabular}{lcccc}
\hline Nozzle & $\begin{array}{c}\mathrm{V} \\
(\mathrm{ml})\end{array}$ & $\begin{array}{c}\mathrm{t} \\
(\mathrm{s})\end{array}$ & $\begin{array}{c}\mathrm{P} \\
(\mathrm{bar})\end{array}$ & $\begin{array}{c}\mathrm{Q} \\
(\mathrm{ml} / \mathrm{s})\end{array}$ \\
\hline Standar & 86 & $5 \mathrm{~s}$ & 1,2 & 17,2 \\
1 Lubang & 17 & 5 & 1,2 & 3,4 \\
\hline
\end{tabular}

Hal ini berbeda dengan penyemprotan konvensional, dimana cairan disemprotkan di atas padi. Dapat diketahui bahwa nilai debit $Q$ untuk nozzle standar pompa manual adalah $17,2 \mathrm{~mL} / \mathrm{s}$ dan untuk nozzle 1 lubang adalah $3,4 \mathrm{~mL} / \mathrm{s}$ dimana $\mathrm{Q}=\mathrm{V} / \mathrm{t}$. Performa pompa DC ditunjukkan pada Tabel 3 dan Tabel 4.

Tabel 3. Performa pompa DC nozzle standar

\begin{tabular}{cccccc}
\hline $\begin{array}{c}\text { Putaran } \\
\text { potensi }\end{array}$ & $\begin{array}{c}\mathrm{R} \\
(\mathrm{k} \Omega\end{array}$ & $\begin{array}{c}\mathrm{V} \\
(\mathrm{ml}\end{array}$ & $\begin{array}{c}\mathrm{t} \\
(\mathrm{s}\end{array}$ & $\begin{array}{c}\mathrm{P} \\
(\mathrm{bar}\end{array}$ & $\begin{array}{c}\mathrm{Q} \\
(\mathrm{ml} / \mathrm{s}\end{array}$ \\
\hline $1 / 3$ & 6,06 & 87 & 5 & ) & ) \\
$2 / 3$ & 4,3 & 140 & 5 & 1,5 & 17,4 \\
1 & 3,68 & 144 & 5 & 1,9 & 28,8 \\
\hline
\end{tabular}

Nilai Q untuk nozzle standar yang terendah adalah $17,4 \mathrm{~mL} / \mathrm{s}$ pada posisi potensiometer di $1 / 3$ putaran. Sementara nilai $Q$ yang tertinggi adalah $28,8 \mathrm{~mL} / \mathrm{s}$ pada posisi potensiometer di 1 putaran.

Tabel 4. Performa pompa DC nozzle 1 lubang

\begin{tabular}{cccccc}
\hline $\begin{array}{c}\text { Putaran } \\
\text { potensi }\end{array}$ & $\begin{array}{c}\mathrm{R} \\
(\mathrm{k} \Omega\end{array}$ & $\begin{array}{c}\mathrm{V} \\
(\mathrm{ml})\end{array}$ & $\begin{array}{c}\mathrm{t} \\
(\mathrm{s}\end{array}$ & $\begin{array}{c}\mathrm{P} \\
(\mathrm{bar}\end{array}$ & $\begin{array}{c}\mathrm{Q} \\
(\mathrm{ml} / \mathrm{s}\end{array}$ \\
\hline $1 / 3$ & 6,06 & 13 & 5 & 1 & 2,6 \\
$2 / 3$ & 4,3 & 18 & 5 & 1,5 & 3,6 \\
1 & 3,68 & 21 & 5 & 1,9 & 4,2 \\
\hline
\end{tabular}

Untuk nilai $\mathrm{Q}$ nozzle 1 lubang yang terendah adalah $2,6 \mathrm{~mL} / \mathrm{s}$ pada posisi potensiometer $1 / 3$, dan yang tertinggi adalah $4,2 \mathrm{~mL} / \mathrm{s}$ pada posisi potensiometer 1 putaran.

\section{b. Perhitungan Volume Penyemprotan per Ha untuk Penyemprotan Bonggol Padi}

Kita ambil jumlah padi yang paling banyak yaitu 16 padi per $\mathrm{m}^{2}$. Dalam hal ini penyemprotan per bonggol padi akan dilakukan selama $0,5 \mathrm{~s}$ menggunakan nozzle 1 lubang karena nozzle ini yang paling hemat. Jumlah padi per ha adalah $16 \mathrm{padi} / \mathrm{m}^{2}$ x 10000 $\mathrm{m}^{2}=160000$ padi. Perhitungannya akan dijelaskan tabel berikut, dimana $\mathrm{V}=\mathrm{Q} \times \mathrm{t}$. Volume Penyemprotan per HA Pompa Manual ditunjukkan pada Tabel 5.
Tabel 5. Volume penyemprotan per HA pompa manual

\begin{tabular}{llll}
\hline $\begin{array}{l}\mathrm{Q} \\
(\mathrm{ml} / \mathrm{s})\end{array}$ & $\begin{array}{l}\mathrm{t} \\
(\mathrm{s})\end{array}$ & $\begin{array}{l}\text { Jumlah } \\
\text { padi }\end{array}$ & $\begin{array}{l}\mathrm{V} \text { per Ha } \\
(\mathrm{ml})\end{array}$ \\
\hline 3,4 & 0,5 & 160000 & 272000 \\
\hline
\end{tabular}

Dengan debit 3,4 ml/s diperoleh volume penyemprotan untuk pompa manual sebesar $272000 \mathrm{ml}$ atau $272 \mathrm{~L}$. Sedangkan untuk volume penyemprotan pompa DC ditunjukkan pada Tabel 6.

Tabel 6. Volume penyemprotan per HA pompa DC

\begin{tabular}{llll}
\hline $\begin{array}{l}\mathrm{Q} \\
(\mathrm{ml} / \mathrm{s})\end{array}$ & $\begin{array}{l}\mathrm{t} \\
(\mathrm{s})\end{array}$ & $\begin{array}{l}\text { Jumlah } \\
\text { padi }\end{array}$ & $\begin{array}{l}\mathrm{V} \text { per Ha } \\
(\mathrm{ml})\end{array}$ \\
\hline 2,6 & 0,5 & 160000 & 208000 \\
3,6 & 0,5 & 160000 & 288000 \\
4,2 & 0,5 & 160000 & 336000 \\
\hline
\end{tabular}

Penyemprotan paling efektif yang dapat dicapai pompa manual adalah $272 \mathrm{~L} / \mathrm{ha}$, dan $208 \mathrm{~L} /$ ha untuk pompa DC. Hal ini berarti kedua volume penyemprotan bonggol padi per ha baik pompa manual maupun pompa DC masuk kategori low volume.

\section{c. Berat Sprayer dan Tingkat Keamanan dalam Penggunaannya \\ Dalam pembuatan sebuah alat, tentu saja} sangat penting untuk memperhatikan berat alat tersebut. Alat dengan berat yang sesuai dan aman akan mengurangi resiko cedera, dan menjamin kenyamanan penggunanya. Spesifikasi alat sprayer manual yang telah dimodifikasi dalam penelitian ini ditunjukkan pada Tabel 7.

Tabel 7. Spesifikasi sprayer setelah dimodifikasi

\begin{tabular}{ll}
\hline Parameter & Nilai \\
\hline Merk & Swan \\
Kapasitas tangki & $13,5 \mathrm{~L}$ \\
Panjang & $335 \mathrm{~mm}$ \\
Lebar & $175+125 \mathrm{~mm}$ \\
Tinggi & $500 \mathrm{~mm}$ \\
Berat kosong & $7,2 \mathrm{~kg}$ \\
Berat isi penuh & $21,1 \mathrm{~kg}$ \\
\hline
\end{tabular}

Pada parameter lebar tangki nilainya adalah $175+125,175$ merupakan lebar tangki utama sedangkan 125 merupakan lebar tumpuan pompa DC dan baterai. Berat tangki penyemprot hasil modifikasi yang terisi penuh adalah $21,1 \mathrm{~kg}$. 


\section{d. Pengujian Performa Baterai}

Pengujian performa baterai dilakukan untuk mengetahui seberapa lama baterai untuk melayani beban, yaitu pompa DC. Untuk mendapatkan hal tersebut diperlukan data spesifikasi baterai aki maupun pompa DC dan dari data tersebut dapat diketahui daya (P) masing - masing alat, $\mathrm{P}=\mathrm{V} \times \mathrm{I}$, dapat dilihat pada Tabel 8.

Tabel 8. Spesifikasi aki dan pompa DC

\begin{tabular}{llll}
\hline Jenis & V(volt) & I (A) & P (Watt) \\
\hline Baterai Aki & 12 & 1,2 & 14,4 \\
Pompa DC & 12 & 3 & 36 \\
\hline
\end{tabular}

Lama ketahanan aki yaitu 24 menit diperoleh dari perbandingan antara daya aki dengan daya beban. Jadi aki tersebut dapat memberi daya pompa DC selama 24 menit, jika kita ingin meningkatkan waktu operasi pompa DC, maka nilai arus (I) baterai aki harus ditingkatkan.

\section{KESIMPULAN}

Dari hasil penelitian yang dilakukan diperoleh beberapa kesimpulan bahwa alat semprot padi merk swan yang semula hanya dapat dioperasikan dengan pompa manual setelah dimodifikasi dapat dioperasikan dengan pompa manual dan pompa DC $12 \mathrm{~V}$. Dari hasil pengujian penyemprotan padi di bonggolnya dengan bantuan kamera endoskopi untuk mengamati dan digunakan nozzle dengan 1 lubang (yang semula mempunyai 4 lubang) diperoleh hasil bahwa setiap penyemprotan 1 bonggol padi selama 0,5 detik dengan jumlah padi sekitar 160000 dan luas lahan 1 ha untuk volume penyemprotan pompa manual adalah 272 L/ha sementara pompa DC adalah 336 L/ha.

\section{UCAPAN TERIMA KASIH}

Ucapan terima kasih kepada LPPM Universitas Singaperbangsa Karawang dalam Hibah Internal skim Lintas Fakultas 2018 atas dukungan finansial.

\section{DAFTAR PUSTAKA}

Aspar, G. (2012). Studi Aplikasi Knapsack Sprayer, Knapsack Power Sprayer, dan Boom Sprayer di PT. Laju Perdana Indah, Palembang, Sumatera Selatan.

Balai Pengkajian Teknologi Pertanian
Yogyakarta. (2007). Penggunaan dan Perawatan Alat Semprot Punggung (Sprayer) (pp.1-18). pp.1-18.

Guntoro, D., Agustina, K., \& Yursida, Y. (2014). Efikasi Herbisida Penoksulam pada Budidaya Padi Sawah Pasang Surut untuk Intensifikasi Lahan Suboptimal. Jurnal Lahan Suboptimal, 2(2), 144-150.

Harefa, T. (1997). Pengaruh Tekanan, Panjang Selang dan Dosis Herbisida Terhadap Jumlah dan Ukuran Diameter Butiran pada Alat Semprot (Sprayer) Bertenaga Traktor Tangan. Institut Pertanian Bogor.

Harry L. Field and John B. Solie. (2007). Introduction to Agricultural Engineering Third Edition. In Springer (3rd ed.). https://doi.org/10.1097/00010694195602000-00016

Hermawan, W. (2012). Kinerja Sprayer Bermotor dalam Aplikasi Pupuk Daun di Perkebunan Tebu. Jurnal Keteknikan Pertanian, 26(2), 91-98.

Kurniawan, T. (2014). Modifikasi Jumlah Nosel Sprayer Gendong Bermotor dan Uji Kinerja pada Berbagai Tekanan Semprot dan Tipe Nosel (Institut Pertanian Bogor). https://doi.org/10.1016/j.cell.2009.01.0 43

LAKIP. (2012). Laporan Akuntabilitas Kinerja Direktorat Jenderal Prasarana dan Sarana Pertanian Tahun 2012 (2012th ed.). https://doi.org/10.1017/CB097811074 15324.004

Litbang Pertanian. (2013). Statistik Litbang Departemen Pertanian.

Prasetio, A. A., \& Wicaksono, K. P. (2017). Efikasi Jenis Herbisida pada Pengendalian Gulma di Tanaman Karet (Hevea brasiliensis Muel. Arg.). PLANTROPICA Journal of Agricultural Science, 2(2), 100107. 